Transportation Research Forum

Book Review: Secure and Tranquil Travel: Preventing Crime and Disorder on Public Transport

Book Author(s): Martha J. Smith and Derek Cornish

Review Author(s): William Huneke

Source: Journal of the Transportation Research Forum, Vol. 45, No. 3 (Fall 2006), pp. 125-126

Published by: Transportation Research Forum

Stable URL: http://www.trforum.org/journal

The Transportation Research Forum, founded in 1958, is an independent, nonprofit organization of transportation professionals who conduct, use, and benefit from research. Its purpose is to provide an impartial meeting ground for carriers, shippers, government officials, consultants, university researchers, suppliers, and others seeking exchange of information and ideas related to both passenger and freight transportation. More information on the Transportation Research Forum can be found on the Web at www.trforum.org. 
Book Reviews

Smith, Martha J., and Cornish, Derek , eds. Secure and Tranquil Travel: Preventing Crime and Disorder on Public Transport. UCL Jill Dando Institute of Crime Science. Portland, OR \& London: Willan Publishing and International Specialized Book Services, Inc., 2006.

ISBN 0-9545607-4-4

\section{Secure and Tranquil Travel}

\section{by William Huneke}

This is a curious book. It harkens back to a different time, a time before 9/11 and after World War II when a transit passenger worried about muggings and robberies, but certainly not terrorism. This book pays scant attention to terrorism, which is extremely odd, considering that the London bombings occurred last year, and the Madrid bombings a year earlier. It is more curious when one considers that this book is from University College London, and one remembers that the London Underground had to deal with bombing threats from the IRA when the Troubles gripped Northern Ireland in the 1970s and 1980s.

Terrorism has to be a priority if transit managers are to achieve "secure and tranquil travel." This book aims to provide guidance to transit managers that will reduce crime and increase ridership because if passengers feel safer, they will ride more mass transit. But this book provides a brief two pages on terrorism.

And the book is very curious in its two-page treatment of terrorism. The editors assert in their conclusion that there are similarities between ordinary crime and terrorism, which they cover in general terms so as not to give terrorists a "primer." ${ }^{\text {"Th }}$ This means, one supposes, that it is acceptable to give ordinary criminals a "primer," because they are probably illiterate or they are teenagers who are cutting class to paint graffiti on transit cars and not reading any texts. Or maybe the terrorists' intellectual stamina is not sufficient to get to the end of the book to see how all the useful stuff to counter ordinary transit crime can be adapted to terrorist crime.

At a minimum the book should have advised transit managers on how to enlist passengers' help in foiling terrorist attacks. It was common to see warnings about unattended baggage during the time of the IRA bombing threat. Similar tactics are possible now without providing a "primer." If a book aims to provide guidance for "secure and tranquil travel" in the current century, it really cannot ignore terrorism. Otherwise it is as useful as the Maginot Line was against the German blitzkrieg in 1940.

The editors present a formulaic approach to achieving "secure and tranquil travel.” It is a three step process:

- Understand the general problem, e.g., attacks on transit employees

- Understand how it affects the local situation, e.g., ticket booth robberies. "Ask the right questions" to define the problem and create measures to see how the situation changes before and after a response is implemented.

- Prepare a response, e.g., use automated machines that have collection activities in a separate space, a room behind the machines that is not available to passengers.

The responses are provided in an elaborate matrix at the end of each chapter focused on particular broad crime categories. The matrix provides a general technique with specific examples, when the example works best, and what other ramifications should be considered.

Unfortunately for the editors, their approach to providing "secure and tranquil travel" may not work so well with terrorists. Their data-driven approach relies on the fact that ordinary transit 
Secure and Tranquil Travel

crimes recur with great frequency. Terrorist crimes generally are one-offs and not ideally suited to a data-driven approach.

On the other hand, Secure and Tranquil Travel has wonderful photos. It has pictures of both criminal activity and countermeasures. For example, it has pictures of train damage caused by projectiles and the countermeasure of a screened in bridge. It also features signage that alerts passengers to potential threats.

The book has useful although not terribly surprising facts to report. Women are more likely to be victims of theft than men, and theft is most likely at rush hour. Thieves use rush hour crowding to their advantage. Men are more likely to suffer assault crimes with alcohol being a likely contributor. Teenagers are the chief perpetrators of graffiti, vandalism and line-of-route crimes. Although suicide is comparatively much less frequent than other crimes, it is the most expensive line-of-route issue for transit managers. ${ }^{2}$ In the 1980 s German authorities witnessed a $175 \%$ increase in transit suicides that coincided with a German TV program, "Death of a Student." The program began each episode with a transit-related suicide. Other suicide rates were unchanged, so it apparently was a copycat stimulus. $^{3}$

There are also cocktail party banter tidbits in Secure and Tranquil Travel. One recommendation is that transit authorities play classical music to discourage teenagers from loitering. This advice prompts speculation that teenagers either have poor music taste or that classical music might encourage them to think, an activity they would prefer to avoid. The book has a particularly intriguing poster, which shows a butcher underneath a display of sausages and smoked meat with the caption: "Don't eat smelly food." This is sponsored by the mayor of London as advice for Tube passengers. One wonders if the nanny state can refrain from a couple more in this vein such as "Brush your teeth" or "Did you wash up before leaving home?"

Secure and Tranquil Travel has much useful information. It provides a thoughtful approach to dealing with ordinary criminal activity. However, it cannot claim to provide a complete approach that leads modern transit to travel that is secure and tranquil. Not in this millennium.

\section{Endnotes}

1. Smith and Cornish, p. 196.

2. Ibid., p. 157

3. Ibid., p. 182

William Huneke is associate director and chief economist at the Surface Transportation Board. He has more than 20 years experience in economics, management consulting, information systems, and teaching. He earned a Ph.D. at the University of Virginia. His dissertation was entitled "The Heavy Hand: The Government and the Union Pacific, 1862-1898." The opinions expressed in this paper are the author's and do not reflect the views or policy positions of Surface Transportation Board. 